\title{
Gambaran Karakteristik dan Luaran pada Preeklamsi Awitan Dini dan Awitan Lanjut Di RSUP Dr. Hasan Sadikin Bandung
}

\author{
Santi Maria Burhanuddin, Sofie Rifayani Krisnadi, Dini Pusianawati \\ Departemen Obstetri dan Ginekologi Fakultas Kedokteran Universitas Padjadjaran \\ Rumah Sakit Dr. Hasan Sadikin Bandung \\ Korespondensi: Santi Maria Burhanudin, Email: mariaburhanuddin23@gmail.com
}

\begin{abstract}
Abstrak
Tujuan: Meneliti karakteristik dan luaran pada preeklamsia awitan dini dan awitan lambat di Rumah Sakit Umum Pusat Dr. Hasan Sadikin Bandung.

Metode: Penelitian deskriptif dengan pendekatan potong lintang. Data diambil dari rekam medis.

Hasil: Terdapat 347 pasien preeklamsi, 137 preeklamsi awitan dini, 192 awitan lambat dan 18 eklamsi. Distribusi umur preeklamsi awitan dini 20 sampai $<30$ tahun yaitu 45 orang $(32,85 \%)$ dan umur $>35$ tahun 45 orang $(32,85 \%)$, pada awitan lambat tersering pada umur $>35$ tahun 64 orang (33,33\%). Distribusi paritas preeklamsi awitan dini paritas 1-3 yaitu 102 orang $(74,5 \%)$ dan awitan lambat 118 orang $(61,5 \%)$. Luaran bayi menunjukkan bayi yang lahir sesuai usia kehamilan pada preeklamsi awitan dini sebanyak 83,9\% dan awitan lambat sebanyak $77,6 \%$ dan nilai APGAR 1 menit 7-10 pada preeklamsi awitan dini adalah 46\% dan awitan lambat adalah 72,4\%. Sindrom HELLP parsial adalah komplikasi terbanyak, yaitu 64 kasus $(18,44 \%), 39$ kasus pada preeklamsi awitan dini, dan 22 kasus pada preeklamsi awitan lambat.

Kesimpulan: Tidak ada perbedaan signifikan luaran bayi antara preeklamsia awitan dini dan awitan lambat. Komplikasi tersering adalah sindroma HELLP parsial.

Kata kunci : Karakteristik, luaran, preeklamsia awitan dini, awitan lambat.

\section{Description of Characteristic and Outcome in Early Onset Preeclampsia and Late Onset Preeclampsia in Dr. Hasan Sadikin General Hospital Bandung}

\begin{abstract}
Objective: To describe the characteristics and outcome in early onset and late onset pre-eclampsia at Dr. Hasan Sadikin General Hospital Bandung.

Method: A cross sectional study with retrospective approach by examining medical record at Dr. Hasan Sadikin General Hospital.

Result: Showed 347 patients preeclampsia,137 early-onset preeclampsia, 192 late-onset and 18 eclampsia. Distribution by age in early-onset preeclampsia by age group 20 to $<30$ years ie 45 women (32.85\%) and age $>35$ years ie 45 women $(32.85 \%)$, late onset age group $>35$ years ie 64 women (33.33. Distribution based on parity in early onset preeclampsia in the 1-3 parity group of 102 women (74.5\%) and late-onset of 118 women (61.5\%). Infant outcome average for gestational age at early-onset of $83.9 \%$ and late-onset of $77.6 \%$ and APGAR value of 1 min 7-10 in early-onset was 46\% and late-onset was 72.4\%. The partial HELLP syndrome was the most common complication, ie 64 cases (18.44\%), with the occurrence of early-onset preeclampsia 39 cases, in the late-onset 22 cases.

Conclusion: No significant difference was found in infant outcome between the two groups. The most common complication is partial HELLP syndrome.
\end{abstract}

Key words: Characteristics, outcomes, early onset preeclampsia, late onset preeclampsia. 


\section{Pendahuluan}

Tiga penyebab kematian ibu terbesar yaitu perdarahan, hipertensi dalam kehamilan (HDK), dan infeksi, namun proporsinya telah berubah, perdarahan dan infeksi cenderung mengalami penurunan sedangkan HDK proporsinya semakin meningkat. Lebih dari 25\% kematian ibu di Indonesia pada tahun 2013 disebabkan oleh HDK. Kematian ibu dan bayi dapat disebabkan oleh faktor yang berasal dari ibu itu sendiri. ${ }^{1}$ Preeklamsi merupakan penyebab utama morbiditas dan mortalitas ibu dan perinatal di seluruh dunia. Hal ini didukung oleh penelitian yang dilakukan WHO, UNFPA dan UNICEF yang menyatakan bahwa preeklamsi-eklamsi merupakan penyebab utama masalah kesehatan di negara berkembang. $^{2}$ Setiap tahun, diperkirakan 50.000 kematian ibu di seluruh dunia dan diperkirakan terdapat $5 \%-7 \%$ kehamilan dengan preeklamsi-eklamsi di seluruh dunia. ${ }^{3}$ Angka kematian ibu akibat preeklamsi dan eklamsi di Indonesia antara 9,8\%-25\%. Angka kejadian preeklamsi dan eklamsi di Indonesia diperkirakan 3,4\%-8,5\%. ${ }^{4}$ Sementara itu di Jawa Barat tercatat 7,4\% kasus preeklamsi dan 1,6\% kasus eklamsi pada tahun 2007-2008..$^{5}$

Preeklamsi merupakan sindrom pada kehamilan yang terutama ditandai dengan hipertensi, proteinuria, dan edema. Preeklamsi tanpa penanganan yang tepat dapat berkembang menjadi eklamsi yang merupakan kondisi fatal berhubungan dengan kejang dan koma. Sekitar 5\% keadaan preeklamsi dapat berkembang menjadi eklamsi. ${ }^{6,7}$

Subklasifikasi preeklamsi dapat dibagi menjadi preeklamsi awitan dini (early-onset) dan preeklamsi awitan lambat (late-onset) berdasarkan saat terdiagnosis secara klinis, dapat juga dibagi menjadi preeklamsi ringan dan preeklamsi berat berdasarkan manifestasi klinis dan laboratoris serta terdapatnya komplikasi. Preeklampsia awitan dini terjadi pada usia kehamilan kurang dari 34 minggu, dan awitan lambat terjadi pada atau setelah usia kehamilan 34 minggu. Preeklamsi awitan dini dan awitan lambat merupakan konsep yang lebih modern, kedua entitas ini memiliki etiologi yang berbeda, namun teori ini masih dalam tahap penelitian.

Dari berbagai penelitian sebelumnya terdapat beberapa perbedaan mendasar diantaranya yaitu pada preeklamsi awitan lambat yang merupakan $80 \%$ kasus preeklamsi dan kebanyakan kasusnya dihubungkan dengan pertumbuhan janin yang baik tanpa adanya tanda-tanda gangguan pertumbuhan janin dengan gambaran velosimetri Doppler arteri uterina yang normal atau sedikit meningkat, tidak terdapat gangguan aliran darah umbilikus dan lebih berisiko pada wanita dengan plasenta yang besar dan luas (diabetes, kehamilan multipel, anemia). Preeklamsi awitan dini (sebelum 34 minggu) yang merupakan $5-20 \%$ dari seluruh preeklamsi berat, namun sering menimbulkan kasus dengan klinis yang berat, dihubungkan dengan adanya invasi trofoblas yang abnormal pada arteri spiralis sehingga menimbulkan perubahan aliran darah di arteri subplasenta, peningkatan resistensi aliran darah plasenta dan arteri umbilikal serta adanya tanda-tanda gangguan pertumbuhan janin. $^{8}$

Preeklamsi-eklamsi dapat mengakibatkan komplikasi terhadap janin maupun ibu. Komplikasi pada janin dapat berupa asfiksia berat, berat badan lahir rendah, maupun preterm infant. Komplikasi juga dapat terjadi pada ibu seperti HELLP (Hemolysis, Elevated Liver Enzymes, Low Platelet) syndrome, cerebrospinal accident, Disseminata Intravascular Coagulation (DIC), gagal jantung, edema paru, gangguan fungsi ginjal, dan kematian. ${ }^{5,9}$

Tingginya angka morbiditas dan mortalitas ibu dan bayi yang disebabkan preeklamsi dan eklamsi membuat peneliti 
bermaksud untuk mengetahui karakteristik ibu preeklamsi di RSUP Hasan Sadikin Bandung berdasarkan rekam medis pasien yang bersalin di RSUP Dr. Hasan Sadikin Bandung periode 1 Mei 2016-30 April 2017.

\section{Metode}

Penelitian ini merupakan penelitian deskriptif dengan desain studi cross sectional (potong lintang) dengan pendekatan retrospektif untuk mengetahui karakteristik dan luaran pada kasus preeklamsi awitan dini dan preeklamsi awitan lambat di RSUP Hasan Sadikin Bandung. Sumber data diperoleh secara sekunder dengan meneliti data rekam medis ibu preeklamsia yang melahirkan di RSUP Dr. Hasan Sadikin Bandung periode Mei 2016 sampai April 2017.

Populasi penelitian ini adalah semua wanita yang melahirkan dengan kasus preeklamsi dan eklamsi di RSUP Dr. Hasan Sadikin Bandung periode 1 Mei 2016-30 April 2017.

Dalam penelitian ini, yang menjadi sampel penelitian adalah semua wanita yang melahirkan dengan kasus preeklamsia dan eklamsi di RSUP Hasan Sadikin Bandung periode 1 Mei 2016 sampai 30 April 2017.

Data yang dikumpulkan merupakan data sekunder yang didapat dari Rekam Medis kasus preeklamsi pada Bagian Obstetri dan Ginekologi di RSUP Dr. Hasan Sadikin Bandung berdasarkan rekam medis periode Mei 2016-April 2017.

\section{Hasil}

Jumlah persalinan di RSUP Dr. Hasan Sadikin Bandung Periode 1 Mei 2016-30 April 2017 sebanyak 2264 persalinan. Jumlah total kasus preeklamsi dan eklamsi sebanyak 347 kasus yaitu $15,32 \%$ dari seluruh persalinan.

Tabel 1 menunjukkan bahwa dari keseluruhan ibu bersalin dengan kasus preeklamsi/eklamsi telah terjadi preeklamsi awitan dini sebanyak 137 orang, preeklamsi awitan lambat sebanyak 192 orang, dan eklamsi sebanyak 18 orang.

\begin{tabular}{cccc}
$\begin{array}{c}\text { Tabel } 1 \\
\text { Distribusi Kejadian Preeklampsi/ } \\
\text { Eklampsi di Rumah Sakit Umum } \\
\text { Pusat Dr. Hasan Sadikin Bandung }\end{array}$ \\
\hline \multicolumn{1}{c}{ Status } & Jumlah & \% & $\begin{array}{c}\text { Total Per- } \\
\text { salinan }\end{array}$ \\
\hline $\begin{array}{l}\text { Preeklamsi } \\
\text { awitan dini }\end{array}$ & 137 & 39,48 & $6,05 \%$ \\
$\begin{array}{l}\text { Preeklamsi } \\
\text { awitan lambat }\end{array}$ & 192 & 55,33 & $8,48 \%$ \\
Eklamsi & 18 & 5,19 & $0,79 \%$ \\
Jumlah & $\mathbf{3 4 7}$ & $\mathbf{1 0 0}$ & $\mathbf{1 5 , 3 2 \%}$ \\
\hline
\end{tabular}

Tabel 2 distribusi berdasarkan pembagian umur kasus preeklamsi/eklamsi terbanyak berada pada usia lebih dari 35 tahun yaitu 115 orang $(33,14 \%)$. Distribusi berdasarkan umur pada kasus preeklamsi awitan dini didominasi oleh kelompok umur 20 sampai kurang dari 30 tahun yaitu sebanyak 45 orang $(32,85 \%)$ dan kelompok umur lebih dari 35 tahun yaitu sebanyak 45 orang $(32,85 \%)$, sedangkan pada kasus preeklamsi awitan lambat terbanyak pada kelompok usia lebih dari 35 tahun yaitu sebanyak 64 orang $(33,33 \%)$, dan pada kasus eklamsi terbanyak pada kelompok umur 20 sampai dibawah 30 tahun yaitu sebanyak 6 orang $(33,33 \%)$ dan kelompok umur lebih dari 35 tahun yaitu sebanyak 6 orang $(33,33 \%)$. Distribusi berdasarkan paritas pada kasus preeklamsi awitan dini terbanyak pada kelompok paritas 1-3 yaitu sebanyak 102 orang $(74,5 \%)$ dan preeklamsi awitan lambat sebanyak 118 orang (61,5\%), sedangkan pada kasus eklamsi terbanyak pada kelompok paritas 0 yaitu sebanyak 9 orang $(50 \%)$.

Tabel 3 menunjukkan luaran bayi pada kasus preeklamsi/eklamsi, terdapat 67 $(19,3 \%)$ bayi yang termasuk kelompok Kecil Masa Kehamilan dan 280 (80,7\%) bayi yang termasuk kelompok Sesuai Masa Kehamilan. 
Tabel 2 Karakteristik Ibu pada Kejadian Preeklamsi/Eklamsi di Rumah Sakit Umum Pusat Dr. Hasan Sadikin Bandung

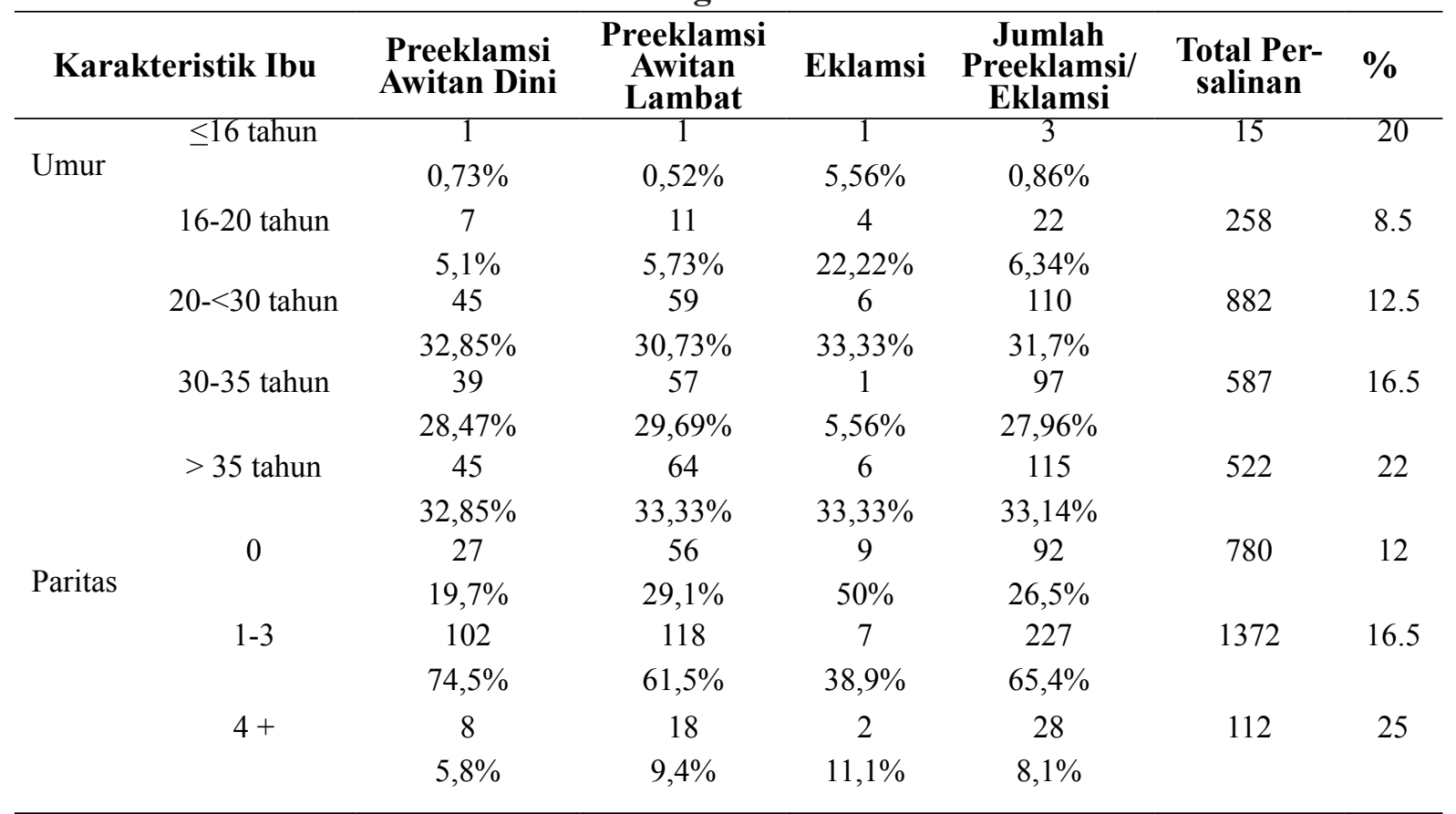

Tabel 3 Luaran Bayi pada Kejadian Preeklamsi/Eklamsi di Rumah Sakit Umum Pusat Dr. Hasan Sadikin Bandung

\begin{tabular}{|c|c|c|c|c|c|c|}
\hline \multicolumn{2}{|c|}{ Luaran Bayi } & \multirow{2}{*}{$\begin{array}{c}\text { Preeklamsi } \\
\text { Awitan Dini } \\
22 \\
16,1 \%\end{array}$} & \multirow{2}{*}{$\begin{array}{c}\begin{array}{c}\text { Preeklamsi } \\
\text { Awitan } \\
\text { Lambat }\end{array} \\
43\end{array}$} & \multirow{2}{*}{$\begin{array}{c}\text { Eklamsi } \\
2\end{array}$} & \multirow{2}{*}{$\begin{array}{c}\begin{array}{c}\text { Jumlah } \\
\text { (n) }\end{array} \\
67\end{array}$} & \multirow{2}{*}{$\begin{array}{c}\begin{array}{c}\text { Persentase } \\
(\%)\end{array} \\
19,3\end{array}$} \\
\hline $\begin{array}{l}\text { Berat Badan } \\
\text { Lahir }\end{array}$ & $\begin{array}{l}\text { Kecil Masa } \\
\text { Kehamilan }\end{array}$ & & & & & \\
\hline & $\begin{array}{l}\text { Sesuai } \\
\text { Masa } \\
\text { Kehamilan }\end{array}$ & $\begin{array}{c}115 \\
83,9 \%\end{array}$ & $\begin{array}{c}149 \\
77,6 \%\end{array}$ & $\begin{array}{c}16 \\
88,89 \%\end{array}$ & 280 & 80,7 \\
\hline \multirow[t]{3}{*}{$\begin{array}{l}\text { APGAR } \\
1 \text { menit }\end{array}$} & 1-3 & $\begin{array}{c}19 \\
14 \%\end{array}$ & $\begin{array}{c}8 \\
4,2 \%\end{array}$ & $\begin{array}{c}1 \\
5,5 \%\end{array}$ & 28 & 8,07 \\
\hline & $4-6$ & $\begin{array}{c}40 \\
29 \%\end{array}$ & $\begin{array}{c}39 \\
20,3 \%\end{array}$ & $\begin{array}{c}9 \\
50 \%\end{array}$ & 88 & 25,36 \\
\hline & $7-10$ & $\begin{array}{c}63 \\
46 \% \\
15\end{array}$ & $\begin{array}{c}139 \\
72,4 \% \\
6\end{array}$ & $\begin{array}{c}7 \\
39 \% \\
1\end{array}$ & 209 & 60,23 \\
\hline Lahir Mati & & $11 \%$ & $3.1 \%$ & $5.5 \%$ & 22 & 6,34 \\
\hline
\end{tabular}

Tabel 4 Luaran Ibu pada Kejadian Preeklamsi/Eklamsi di Rumah Sakit Umum Pusat Dr. Hasan Sadikin Bandung

\begin{tabular}{lccccc}
\hline \multicolumn{1}{c}{ Luaran Ibu } & $\begin{array}{c}\text { Preeklamsia } \\
\text { Awitan Dini }\end{array}$ & $\begin{array}{c}\text { Preeklamsia } \\
\text { Awitan Lambat }\end{array}$ & Eklamsia & Jumlah & $\mathbf{\%}$ \\
\hline Partial HELLP Syndrome & 39 & 22 & 3 & 64 & 18,44 \\
HELLP Syndrome & 19 & 9 & 1 & 29 & 8,36 \\
Gagal Jantung & 18 & 13 & 0 & 31 & 8,93 \\
Edema Paru & 0 & 1 & 0 & 1 & 0,29 \\
TOTAL & & & & 125 & 36,02 \\
\hline
\end{tabular}


Distribusi luaran bayi berdasarkan nilai APGAR 1 menit didapatkan 28 bayi $(8,07 \%)$ dengan nilai APGAR 1 menit 1-3, terdapat 88 bayi $(25,36 \%)$ dengan nilai APGAR 1 menit 4-6, dan 209 bayi $(60,23 \%)$ dengan nilai APGAR 1 menit 7-10. Pada tabel di atas juga menunjukkan terdapat 22 bayi $(6,34 \%)$ yang lahir mati. Luaran bayi pada kasus preeklamsi menunjukkan hasil terbanyak sesuai masa kehamilan yaitu pada preeklamsi awitan dini $83,9 \%$ dan preeklamsi awitan lambat $77,6 \%$ dan nilai APGAR 1 menit pada preeklamsi awitan dini terbanyak pada nilai APGAR 7-10 yaitu $46 \%$ dan preeklamsia awitan lambat $72,4 \%$.

Tabel 4 menunjukkan luaran ibu pada kasus preeklamsi/eklamsi, yaitu terdapat 125 ibu yang mengalami komplikasi dari 347 kasus preeklamsi/eklamsi. Komplikasi partial HELLP syndrome merupakan komplikasi terbanyak, yaitu terdapat 64 kasus $(18,44 \%)$, dengan distribusi kejadian pada kelompok preeklamsi awitan dini terjadi 39 kasus, pada kelompok preeklamsi awitan lambat sebanyak 22 kasus.

\section{Pembahasan}

Penelitian yang dilakukan di RSUP Dr. Hasan Sadikin Bandung dengan metode penelitian deskriptif rektrospektif dan mengambil data sekunder melalui data rekam medis pasien pada 1 Mei 2016-30 April 2017 menunjukkan bahwa berdasarkan hasil pengumpulan data pasien dengan preeklamsi lebih banyak ditemukan pasien dengan preeklamsi awitan lambat yaitu sebanyak 192 orang $(55,33 \%)$ dibandingkan pasien dengan preeklamsi awitan dini yaitu 137 orang $(39,48)$ dan eklamsi yaitu 18 orang $(5,19 \%)$ dari keseluruhan pasien yang didiagnosis dengan preeklampsi yaitu sebanyak 347 orang.

Hasil penelitian karakteristik pasien preeklamsi berdasarkan umur menunjukkan bahwa pasien dengan kelompok umur 20-<30 tahun dan kelompok umur lebih dari 35 tahun lebih mendominasi pada pasien preeklampsi awitan dini yaitu masing-masing sebanyak 45 orang $(32,85 \%)$ dan pada preeklampsi awitan lambat lebih banyak terjadi pada kelompok umur diatas 35 tahun sebanyak 64 orang $(33,3 \%)$. Hal ini sesuai dengan hasil penelitian yang dilakukan pada tahun 2010 oleh Estina V. C. dimana dapat disimpulkan kejadian preeklamsi tersering pada kelompok umur yang termasuk usia produktif untuk merencanakan kehamilan. ${ }^{10}$

Ibu dengan usia $<20$ tahun atau $>35$ tahun dianggap sebagai salah satu risiko untuk mengalami preeklamsi. Usia produktif seorang wanita adalah 20-35 tahun. Dari hasil penelitian yang dilakukan oleh Rozikhan pada tahun 2007, didapatkan hasil bahwa ibu dengan usia $<20$ tahun memiliki hubungan terhadap kejadian preeklamsi berat. ${ }^{11}$ Penelitian Aghamohammadi dan Nooritajer pada tahun 2011, didapatkan hasil bahwa terdapat hubungan usia ibu $>35$ tahun terhadap kejadian preeklamsi berat. ${ }^{12}$ Hasil penelitian Langelo dkk pada tahun 2012 menunjukkan bahwa usia ibu dengan risiko tinggi memilki pengaruh terhadap kejadian preeklamsi berat. ${ }^{13}$ Pada penelitian Parracordero dkk yang dilakukan pada tahun 2002 samapi 2010 mengenai prediksi preeklamsia awitan dini dan awitan lambat berdasarkan karakteristik maternal, didapatkan usia maternal pada preeklamsia awitan dini yaitu $29,7(1,8)$ dan preeklamsia awitan lambat $30,4(0,8) .^{14}$

Hasil penelitian karakteristik pasien preeklamsi berdasarkan jumlah paritas menunjukkan bahwa pasien dengan kelompok jumlah paritas terbanyak adalah pada kelompok paritas 1-3 dengan jumlah pada preeklamsi awitan dini sebanyak 102 orang $(74,5 \%)$ dan pada preeklamsi awitan lambat 118 orang $(61,5 \%)$, sedangkan pada kasus eklamsi terbanyak adalah pada kelompok paritas 0 sebanyak 9 orang (50\%). Hasil penelitian ini tidak sesuai dengan hasil penelitian yang di lakukan pada tahun 2010 
oleh Estina V. C. yang menyatakan penderita preeklamsi tertinggi pada kelompok primigravida $(49,2 \%){ }^{10}$

Berdasarkan awitannya, preeklamsia diklasifikasikan menjadi preeklamsia awitan dini dan awitan lanjut. Preeklamsia awitan dini adalah preeklamsia yang terjadi sebelum kehamilan 34 minggu, sedangkan preeklamsia awitan lanjut adalah terjadi pada atau setelah kehamilan 34 minggu Pengklasifikasian preeklamsia berdasarkan awitan dikarenakan perbedaan faktor yang berpengaruh terhadap patogenesis penyakitnya. Preeklamsia awitan dini berkaitan dengan kelainan plasenta, sedangkan preeklamsia awitan lanjut lebih banyak berkaitan dengan kelainan pada ibu, misalnya kelainan metabolik seperti diabetes dan obesitas. Kelainan plasenta pada preeklamsia awitan dini berupa invasi trofoblas abnormal akan menyebabkan arteri spiralis gagal untuk berdilatasi dan akhirnya terjadi penurunan aliran darah uteroplasenta. Penurunan aliran darah ini dapat menyebabkan terjadinya pertumbuhan janin terhambat, sedangkan pada preeklamsia awitan lanjut tidak terjadi invasi trofoblas abnormal sehingga pengaruh preeklamsia berat awitan lambat terhadap pertumbuhan janin lebih sedikit dibanding preeklamsia berat awitan dini. ${ }^{8,15}$

Data penelitian mengenai luaran bayi yang lahir dengan berat badan yang termasuk dalam kelompok kurang masa kehamilan (KMK) diketahui sebanyak 67 bayi (19,3\%) sementara 280 bayi $(80,7 \%)$ lahir dengan berat badan lahir sesuai masa kehamilan (SMK). Dari data penelitian juga didapatkan 28 bayi $(8,07 \%)$ lahir dengan nilai APGAR $1-3$ atau asfiksia berat, dan terdapat 88 bayi (25,36\%) lahir dengan nilai APGAR 4-6 atau asfiksia sedang, dan terdapat 22 bayi $(6,34 \%)$ yang lahir mati. Hasil penelitian ini memperkuat hasil penelitian Raras (2011) yang menyimpulkan pasien preeklamsia berat memiliki prevalensi efek samping merugikan yang besar dengan tingkat morbiditas dan mortalitas yang tinggi sehingga dapat mempengaruhi luaran maternal dan perinatal. Luaran perinatal meliputi bayi berat lahir rendah (BBLR) 91 kasus (37\%), pertumbuhan janin terhambat 17 kasus (6,9\%), kelahiran preterm 70 kasus $(28,3 \%)$, asfiksia neonatorum 38 kasus $(16,7 \%)$, kematian perinatal 23 kasus $(9,3 \%)$. Nilai rasio prevalensi sebesar 2,927 mempunyai arti bahwa ibu dengan preeklamsia berat mempunyai risiko sebesar 2,927 kali lebih besar mengalami persalinan dengan BBLR.16 Ibu yang menderita preeklampsi hanya waktu hamil, akan mengalami disfungsi plasenta yang dapat menyebabkan aliran darah ke plasenta terganggu, sehingga kebutuhan janin akan nutrisi dan oksigen tidak dipenuhi secara optimal. Sebagian besar arteri spiralis di daerah miometrium tetap dalam keadaan kontriksi sehingga tidak mampu memenuhi kebutuhan nutrisi dan oksigen untuk janin sehingga gangguan pertumbuhan janin pada ibu dengan preeklampsi terjadi akibat hipoperfusi plasenta. Spasme yang berlangsung lama mengakibatkan gangguan fungsi plasenta sehingga menyebabkan pertumbuhan janin terganggu. Bila terjadi spasme arteriol yang lama tanpa disertai dengan kenaikan tonus otot uterus dan kepekaan terhadap perangsangan maka akan terjadi kelahiran bayi kecil untuk masa kehamilan. ${ }^{17}$

Luaran ibu terdapat 125 ibu $(36,02 \%)$ yang mengalami komplikasi pada kehamilannya dengan komplikasi terbanyak berupa partial HELLP syndrome yaitu 64 orang $(18,44 \%)$, dan HELLP Syndrome 28 orang $(8,36 \%)$. Menurut Sibai dkk kejadian sindroma HELLP berkisar 2-12\% dari seluruh penderita preeklampsia berat.18 Sedangkan angka kejadian sindroma HELLP pada seluruh kehamilan berkisar antara 0,2 sampai 0,6\%. Di RS Dr. Pirngadi Medan menurut penelitian Siregar (1997) yang dilakukan selama satu tahun angka kejadian sindroma HELLP didapati 1,54\% (1) kasus dari 65 
kasus preeklamsia berat dan eklamsia. ${ }^{19}$ Sofoewan (2000) melaporkan pada penelitian retrospektif di RS Dr. Sardjito Yogyakarta didapati 3 kasus $(4,4 \%)$ sidroma HELLP Murni dan 11 kasus (16,2\%) sindroma HELLP Parsial dari 68 kasus preeklampsia berat yang ditelitinya sejak Januari1998 sampai September 2000. ${ }^{20}$ Simpulan: (1) kasus preeklamsi yang terbanyak adalah preeklamsi awitan lambat sebanyak 192 kasus (55.33\%). Paritas 1-3 merupakan kelompok yang terbanyak pada kejadian preeklamsi awitan dini 102 orang $(74,5 \%)$ dan awitan lambat 118 orang $(61,5 \%)$, namun pada kejadian eklamsi kelompok paritas 0 merupakan yang terbanyak yaitu 9 orang (50\%). (2) kejadian preeklamsi meningkatkan risiko terhadap luaran perinatal. Luaran bayi kecil masa kehamilan pada kasus preeklamsi awitan dini sebanyak 22 bayi (16.1\%), preeklamsi awitan lambat 43 bayi (22.4\%), dan eklamsi 2 bayi (11.11\%). Luaran bayi berdasarkan nilai APGAR terbanyak pada kelompok 7-10, namun didapatkan lahir mati sebanyak 22 bayi (6.34\%) dengan distribusi terbanyak pada preeklamsi awitan dini 15 (11\%). (3) Luaran ibu didapatkan 125 orang (36.02\%) yang mengalami komplikasi, terbanyak yaitu partial HELLP syndrome 64 orang (18.44\%) dengan distribusi terbanyak pada preeklamsi awitan dini.

\section{Daftar Pustaka}

1. Kementerian Kesehatan Republik Indonesia. Profil Kesehatan Indonesia 2015. Edisi. Jakarta: Pusat Data dan Informasi Kementerian Kesehatan RI; 2016.

2. WHO. Maternal Mortality Rate. 2013 [diunduh tanggal 10 mei 2017]; Tersedia dari: <http://www.who.int/ maternal_child_adolescent/news_events/ news/2013/countdown_2015_progress/ en $/>$.

3. Huppertz B. Placental Origins of
Preeklampsia: Challenging the Current Hipothesis. Hypertension. 2008. p. 9705.

4. Tribawono A. Pengelolaan preeklamsieklamsi di RSUP Dr. Hasan Sadikin Bandung. Naskah lengkap POGI Bandung di PIT XIII Malang Bagian/ SMF Obgin FK Unpad /RSUP Dr Hasan Sadikin Bandung. 2002.

5. Martaadisoebrata D, Wirakusumah F, Effendi J. Obstetri Patologi. Jakarta: EGC; 2013.

6. Cunningham FG, Gant NF, Leveno KJ, Gilstrap LC Hypertensive disorder in pregnancy. William Obstetric. 23 ed. United States of America: McGraw-Hill; 2005. p. 741-808.

7. Sudhaberata K. Penanganan Pre Eklampsia Berat dan Eklampsi. Cermin Dunia Kedokteran. UPF Ilmu Kebidanan dan Penyakit Kandungan RSU Tarakan Kalimantan Timur. 2008;26-30.

8. Bas B. van Rijn. Early onset preeclampsia. Constitutional factors and consequences for future pregnancy outcome and cardiovascular health. Thesis, Utrecht University, 2008

9. Solomon CGS, Ellen W. Hypertension in Pregnancy. Endrocinol Metab Clin N Am 35.2011.Dec;40 (4);847-63.

10. Estina V C, Delima E R, Gunanegara R F. Karakteristik Penderita Preeklamsi dan Eklamsi yang Dirawat Inap di Rumah Sakit Immanuel Bandung Periode Tahun 2006 - 2008. JKM. 2010;9:150-54.

11. Rozikhan. Faktor-faktor risiko terjadinya pre- eklampsia berat di rumah sakit Dr. H. Soewondo Kendal (tesis). Semarang: Universitas Diponegoro; 2007.

12. Aghamohammadi A, Nooritajer $M$. Maternal age as a risk factor for pregnancy outcomes: maternal, fetal and neonatal complication. Afr J Pharm Pharmacol. 2011;5(2): p 264-9.

13. Langelo W, Arsin AA, Russeng S. Faktor risiko kejadian preeklampsia Di RSKD 
Ibu dan Anak Siti Fatimah Makassar Tahun 2011-2012. Makassar: Universitas Hasanuddin; 2012.

14. Parra-cordero $\mathrm{M}$, rodrigo $\mathrm{R}$, Barja P, Bosco C, Rencoret G, Sepulvedamartinez A, Quezada S. Prediction of early and late preeclampsia from maternal characteristic, uterine artery doppler and markers of vasculogenesis during first trimester of pregnancy. Ultrasound Obstet Gynecol. 2013;41:538-544.

15. Roberts J, Hubel C. The two stage model of preeclampsia: variations on the theme. J.Placenta. 2009;30: S32-S37.

16. Raras AA, 2011. Pengaruh Preeklamsia Berat Pada Kehamilan Terhadap Keluaran Maternal Dan Perinatal Di RSUP Dr. Kariadi Semarang Tahun 2010. Artikel penelitan. Fakultas Kedokteran Universitas Diponegoro.
17. Winkjosastro H., 2007. Ilmu Kebidanan. Edisi ketiga, cetakan kesembilan, Yayasan Bina Pustaka Sarwono Prawihardjo, Jakarta. p. 281-301.

18. Sibai BM. The HELLP Syndrome (hemolysis, elevated liver enzymes and low trombosit counts) : Much ado About Nothing ?. AmJ Obstet Gynecol 1990 ; $162: 311-6$.

19. Siregar MF. Luaran Janin dan Ibu pada Penderita Preeklampsiaa di RSUD Dr. Pirngadi Medan. Medan : Universitas Sumatera Utara. Tesis. 1997.

20. Sofoewan S. Pregnancy Outcome of Women with Severe Preeclampsia With and Without HELLP Syndrome. Dalam : AUFOG Accredited Ultrasound and Workshop. Bandung. 2001. 